\title{
O papel do juiz no Estado Democrático de Direito: por uma perspectiva garantista no julgamento do caso da interrupção da gestação do concepto anencefálico submetido à jurisdição constitucional
}

\author{
Liliam Cristina de Souza Teixeira ${ }^{1}$
}

\begin{abstract}
Resumo
Objetiva analisar, a partir do caso da interrupção da gravidez do concepto anencefálico, hoje submetido à jurisdição constitucional, a postura do julgador no Estado Democrático de Direito. Utiliza-se de material doutrinário, jurisprudências e artigos divulgados em revistas e na Internet. Apresenta a legislação vigente no país no que pertine ao termo inicial e final da vida; os posicionamentos divergentes adotados pelo Judiciário na análise do caso; a repercussão do debate na sociedade e os aspectos jurídico-filosóficos enfrentados pelo julgador na apreciação da questão. Destaca como ponto de partida dois eixos analíticos: procedimentalismo e substancialismo. Explicita a teoria geral do garantismo, eminentemente substancialista, expondo as três acepções do termo. Aponta como principais resultados, norte para solução do problema: a) a necessária opção, no Brasil, pela visão substancialista, já que traz a Constituição direitos fundamentais a serem concretizados independentemente da vontade do grupo majoritário; b) a releitura da democracia no Estado Democrático de Direito, como síntese da democracia substancial e da formal; c) a legitimidade do exercício do poder pautada na concretização dos direitos fundamentais. Conclui-se que a adoção do modelo de Estado Democrático de Direito implica na postura ativa do juiz visando ao alargamento da ação protetiva dos direitos fundamentais.
\end{abstract}

Palavras-Chave: Estado Democrático de Direito; Substancialismo; Garantismo; Direitos Fundamentais; Democracia; Concepto anencefálico.

\section{Introdução}

Questões sobre quando começa a vida e, conseqüentemente, desde quando deve ser juridicamente tutelada e sobre quando termina, ou até quando deve ser protegida na esfera jurídica, sempre suscitaram ferozes controvérsias.

O Legislador pátrio se posicionou pela proteção do bem jurídico vida desde a concepção, punindo penalmente o abortamento. Frise-se que a tipificação do crime foi feita na Parte Especial do Código Penal, sob o Título I, Dos crimes contra a pessoa, Capítulo I, Dos

1 Especialista em Direito do Estado - Direito Constitucional pela Universidade Estadual de Londrina. 
crimes contra a vida, artigos 124 a $128^{2}$. Assim, os operadores do direito sempre tiveram a certeza de que o crime de aborto incorporava, em seu tipo objetivo, a necessidade de que o feto estivesse vivo quando da interrupção da gestação.

No outro extremo da vida, a morte.

Os avanços científico-tecnológicos tornaram possível à medicina a adoção de procedimentos para prolongar a vida: é possível manter pessoas ligadas a aparelhos, sem os quais perderiam a maior parte - senão todas - suas funções vitais, por meses ou anos; é possível, ainda, prolongar a vida de um indivíduo mediante transplante de órgãos sadios ao enfermo.

A Lei no. 9.434/97, que dispõe sobre a retirada de órgãos para fins de transplante ou tratamento, giza que somente é permitida a retirada do corpo vivo quando se tratar de órgãos duplos, de partes de órgãos, tecidos ou partes do corpo cuja retirada não impeça o organismo do doador de continuar vivendo sem risco para a sua integridade e não represente grave comprometimento de suas aptidões vitais e saúde mental, não cause mutilação ou deformação inaceitável, e corresponda a uma necessidade terapêutica comprovadamente indispensável à pessoa receptora (art.9으, §3ㅇ).

Nos demais casos, só é aceita a doação de órgãos "post mortem".

Mas em que momento se caracteriza a morte?

Clareia o art. 3 do referido diploma legislativo que a retirada "post mortem" de tecidos, órgãos ou partes do corpo humano destinados a transplante ou tratamento deverá ser precedida de diagnóstico de morte encefálica, constatada e registrada por dois médicos

2 Aborto provocado pela gestante ou com seu consentimento - Art. 124 - Provocar aborto em si mesma ou consentir que outrem lho provoque: Pena - detenção, de um a três anos; Aborto provocado por terceiro Art. 125 - Provocar aborto, sem o consentimento da gestante: Pena - reclusão, de três a dez anos.; Art. 126 - Provocar aborto com o consentimento da gestante: Pena - reclusão, de um a quatro anos. Parágrafo único. Aplica-se a pena do artigo anterior, se a gestante não é maior de quatorze anos, ou é alienada ou débil mental, ou se o consentimento é obtido mediante fraude, grave ameaça ou violência; Forma qualificada - Art. 127 - As penas cominadas nos dois artigos anteriores são aumentadas de um terço, se, em conseqüência do aborto ou dos meios empregados para provocá-lo, a gestante sofre lesão corporal de natureza grave; e são duplicadas, se, por qualquer dessas causas, Ihe sobrevém a morte; Art. 128 - Não se pune o aborto praticado por médico: Aborto necessário - I - se não há outro meio de salvar a vida da gestante; Aborto no caso de gravidez resultante de estupro - II - se a gravidez resulta de estupro e o aborto é precedido de consentimento da gestante ou, quando incapaz, de seu representante legal. 
O papel do juiz no Estado Democrático de Direito: por uma perspectiva garantista no julgamento do caso da interrupção da gestação do concepto anencefálico submetido à jurisdição constitucional

não participantes das equipes de remoção e transplante, mediante a utilização de critérios clínicos e tecnológicos definidos por resolução do Conselho Federal de Medicina ${ }^{3}$.

Apresentada a posição do legislador brasileiro sobre os dois extremos da vida, pareceria fácil julgar uma ação cujo objeto fosse o requerimento de alvará judicial para interrupção antecipada da gravidez do concepto anencefálico.

Pareceria fácil! A questão, porém, envolve aspectos, além de jurídicos, filosóficos e ético-religiosos, conforme se apontará no presente artigo.

Num primeiro momento, será apresentada uma contextualização: os posicionamentos adotados pelo Judiciário e os debates na sociedade; após, os aspectos jurídico-filosóficos enfrentados, tudo com o fim de analisar, a partir deste caso paradigmático, a postura esperada do julgador num Estado Constitucional Democrático de Direito, tal qual o é a República Federativa do Brasil.

\section{Da postura do poder judiciário na apreciação da (in)existência de direito constitucional da gestante para a interrupção antecipada da gravidez de feto anencefálico}

Diante do requerimento de alvará para interrupção antecipada do processo gestacional do feto anencefálico, emergem do Judiciário ao menos três interpretações distintas.

Para uma corrente jurisprudencial não há abortamento - retirada da vida de um feto - e, portanto, não há crime. Não se vislumbra um bem jurídico tutelável, não se vislumbra um objeto jurídico, tampouco, um sujeito passivo. Ter-se-ia o crime impossível.

Numa outra interpretação, afirma-se que o ato é albergado por uma excludente supra-legal de antijuridicidade: a inexigibilidade de conduta diversa. "O direito não pode

\footnotetext{
A Resolução CFM no. 1.480/97, em seu artigo 3ำ, cita que a morte encefálica deverá ser conseqüência de processo irreversível e de causa conhecida. Por sua vez, a Resolução CFM no. 1.752/04, dispondo sobre a doação de órgãos e/ou tecidos dos fetos anencefálicos, ressalta que, autorizado formalmente pelos pais, no mínimo 15 (quinze) dias antes da data provável do parto, o médico poderá realizar o transplante logo após o nascimento do anencéfalo. Dentre as considerações para a Resolução 1.752/04, destacamos: a) que os anencéfalos são natimortos cerebrais (por não possuírem os hemisférios cerebrais) que têm parada cardiorrespiratória ainda durante as primeiras horas pós-parto; b) que para os anencéfalos, por sua inviabilidade vital em decorrência da ausência de cérebro, são inaplicáveis e desnecessários os critérios de morte encefálica; c) que a anencefalia é um processo irreversível, de causa conhecida e sem qualquer possibilidade de sobrevida.
} 
exigir das pessoas comportamentos heróicos", defendem. Outra nuance deste posicionamento, é feito através de uma análise contrafactual ${ }^{4}$, argumentando que o fato só não foi previsto pelo Legislador dentre os incisos do art. 128 do Código Penal porque, em 1940, a medicina não dispunha de recursos técnicos que permitissem a detecção da anomalia. Então, fazem os julgadores uma interpretação extensiva das hipóteses do dispositivo legal, pautada na "mens legis".

Outros, enfim, consideram a conduta típica e salientam que não há previsão pelo Legislador de excludente de ilicitude, de modo que o Judiciário, órgão não politizado, não possuiria legitimidade, num Estado Democrático, para descriminalizar a conduta.

Diante de diversas ações objetivando alvarás judiciais para a interrupção antecipada da gravidez de feto anencefálico, abalizadas sempre nos direitos fundamentais da gestante, e diante do desencontro de entendimentos externados nas decisões judiciais, formalizou-se, em 17/06/2004 ${ }^{5}$, a Argüição de Descumprimento de Preceito Fundamental no. 54-8, na qual se requer a interpretação dos supracitados dispositivos do Código Penal em conformidade com a Constituição (interpretação conforme a Constituição).

Em 01/07/2004, foi deferida a medida acautelatória pelo Ministro Relator Marco Aurélio Mendes de Faria Mello, para não só sobrestar os processos e decisões não transitadas em julgado ${ }^{6}$, como também para reconhecer o direito constitucional da gestante de se submeter à operação terapêutica de parto de fetos anencefálicos, a partir de laudo médico atestando a anomalia, decisão esta que, submetida ao referendo do Pleno, foi parcialmente revogada.

Por sua vez, em 28 de setembro de 2004, o E. Ministro Relator, reconhecendo que a decisão da ADPF no. 54-8 gerará efeitos imediatos e relevantes para a sociedade brasileira,

\footnotetext{
4 Sobre análise de casos complexos através de questões contrafactuais, DWORKIN (2005). A indagação formulada pelo intérprete na análise de lacunas legislativas, através da questão confrafactual, é a seguinte: como seria a legislação se, contrário ao fato, houvesse o Legislador deliberado sobre o caso ora controverso?

5 Em 17/06/2004, foi impetrado no STF o HC 84.025/RJ, significando ao Supremo Tribunal Federal a primeira oportunidade de apreciar a questão da (in)constitucionalidade da interrupção antecipada da gravidez de feto anencefálico. Em 04/03/2004, foi o Hábeas Corpus julgado prejudicado devido à superveniente perda de objeto. Aos 28/02/2004, nascia Maria Vida, que sobreviveu por apenas 07 (sete) minutos. Disponível em: $<$ http://www.stf.gov.br>

6 Há críticas sobre os efeitos que podem ser gerados na medida acautelatória das ações objetivas de jurisdição constitucional, nos termos das Leis no. 9.868/99 e 9.882/99. Sarlet (2001) salienta que estes dispositivos legais já suscitaram muitas críticas, inclusive antes da entrada em vigor de ambas as leis, sob o argumento de que reintroduziriam no ordenamento pátrio a famigerada avocatória.
} 
O papel do juiz no Estado Democrático de Direito: por uma perspectiva garantista no julgamento do caso da interrupção da gestação do concepto anencefálico submetido à jurisdição constitucional

envolvendo questões múltiplas - jurídicas e extrajurídicas, entendeu conveniente acionar o artigo 6 ㅇ, $\S 1$ 으, da Lei $\mathrm{n}$ ㅇ. 9.882/1999, deferindo a oitiva das entidades que haviam requerido fossem aceitas como "amicus curiae" em audiência pública.

Em 20/10/2004, revogou-se a parte da acautelatória que autorizava a interrupção antecipada da gestação, porém, referendou-se no tocante à suspensão dos processos e dos efeitos das decisões judiciais não transitadas em julgado.

Situação vivida no país que é o quarto no ranking mundial de fetos anencefálicos, com uma média de 615 mortes anuais decorrentes desta doença ${ }^{7}$.

\subsection{Considerações sobre as decisões judiciais e os debates na sociedade}

Na petição inicial da ADPF 54-8, o ilustre causídico Luís Roberto Barroso, cônscio da polêmica existente em torno da legalização do abortamento, cuidou em frisar que, no caso levado ao STF, não há bens jurídicos em conflito a serem tutelados: configurada juridicamente a morte do concepto, porque anencéfalo, só restaria concretizar os direitos fundamentais da gestante, tais quais o direito à liberdade de escolha, à dignidade da condição humana, à saúde.

Ainda que diante dos argumentos do professor da Universidade Estadual do Rio de Janeiro, a questão foi alçada ao tradicional debate entre os "pró-escolha" e os "próvida". Estes, vêem no pedido formulado perante o Supremo Tribunal Federal uma sinalização para a total descriminalização, por vias extra-legislativas, do abortamento de cariz eugênico ${ }^{8}$. Aqueles empenham a bandeira do direito da autonomia da mulher não só no caso posto a julgamento.

O resultado, no momento, é justamente o oposto do que almejava o advogado da Confederação Nacional dos Trabalhadores na Saúde - CNTS, que formalizou a Argüição: a suspensão de todos os processos e dos efeitos das decisões judiciais não transitadas em

7 Segundo dados da Organização Mundial da Saúde o Brasil é o quarto Estado no ranking de nascimento de fetos com esta anomalia, atrás apenas do México, Chile e Paraguai. Para cada 10 mil crianças brasileiras nascidas vivas, há o registro de 8,6 fetos com anencefalia, com uma média anual de 615 mortes de anencéfalos (apud BARBOSA, Joaquim. Argüição de Descumprimento de Preceito Fundamental 54-8, [Voto de Questão de Ordem] Disponível em: <http://www.stf.gov.br> Acesso em 09.09.2005.

8 O aborto eugênico pressupõe, porém, viabilidade de vida extra-uterina, embora seja o feto portador de anomalia comprometedora da higidez mental e física. No caso do anencéfalo, possibilidade de vida extrauterina não há. 
julgado cuja pretensão envolva a matéria; e a existência de fatores exógenos compondo o processo, com influência nitidamente religiosa.

A sugestividade de influências religiosas é de melindrar qualquer bom componente argumentativo, quanto mais se resvalar no julgado, o que poderia retirar-lhe a integridade.

E os argumentos religiosos resvalam em julgados, conforme pode ser verificado na decisão denegando a segurança no Mandado de Segurança $01.000148-4^{9}$ que tramitou no Tribunal de Justiça de Rondônia.

Parece apropriado relembrar a ponderação do ex-presidente francês Valéry Giscard D’Estaing, em diálogo com o papa João Paulo II:

Eu sou católico, mas também sou presidente de uma República cujo Estado é laico [...] Compreendo perfeitamente o ponto de vista da Igreja Católica e, como cristão, o compartilho. Julgo legítimo que a Igreja peça aos que praticam sua fé o respeito a certas proibições, mas não corresponde à lei civil impô-las com sanções penais ao conjunto do corpo social. (D'ESTAING, apud PIOVESAN;PIMENTEL, 2005, p. 42)

O Estado brasileiro é laico. Não pode ter religião oficial, tampouco impor qualquer prática religiosa aos seus nacionais. Também os julgamentos devem ser isentos de influência religiosa.

O Ministro Marco Aurélio Mendes de Faria Mello, na ocasião da declaração de perda de objeto do Hábeas Corpus no. 84.025/RJ, impetrado inicialmente no Superior Tribunal de Justiça pelo padre Luiz Carlos Lodi da Cruz, presidente da Associação Pró-vida em Anápolis (GO), destacou que o dogmatismo religioso e a intolerância estatal são extremamente opressivas à liberdade dos indivíduos, constituindo-se em instrumento de

9 Afirmações tais quais perplexidade ante ao pedido de aborto "após sete meses de gestação"; vida e morte natural, ainda que do anencefálico, como "princípio que nos ensina a ordem do universo"; "mês a mais mês a menos, ocorrerá o nascimento. Por que não aguardar o processo natural?" nas palavras do Desembargador Eliseu Fernandes de Souza; e ainda, "muita perplexidade, com muita reflexão esse comportamento de delegar a nós humanos a retirada de uma vida", nos dizeres do Desembargados José Pedro do Couto, deixou o Desembargador Roosevelt Queiroz Costa irresignado. Pedindo a palavra, manifestou-se: "Sr. Presidente, pela ordem, gostaria de acrescentar neste momento o seguinte: Como ser humano, sensível aos valores e ao bem mais precioso que é a vida, também na condição de cristão, seguidor de um Cristo Vivo que a tudo e a todos governa, ensina e instrui, jamais seria contra as manifestações refutando o aborto. De modo que as endosso integralmente, jamais discordando, especialmente da feliz e correta posição e justa dos Desembargadores Eliseu Fernandes de Souza e José Pedro do Couto. Contudo, nas circunstâncias apresentadas, considerando ainda o desfecho presumido, quase certo já da realização do aborto, só faltando a certidão de óbito nos autos, a minha conclusão do voto perdura". Origem do Mandado de Segurança: Juízo de Direito da 1ạ Vara do Tribunal do Júri de Porto Velho/RO. Disponível em <www.tj.ro.gov.br> 
O papel do juiz no Estado Democrático de Direito: por uma perspectiva garantista no julgamento do caso da interrupção da gestação do concepto anencefálico submetido à jurisdição constitucional

autoritária restrição ao livre arbítrio e à auto-determinação das pessoas, até em questões em que haveriam ser essencialmente livres, tal qual a da avaliação de assuntos pertinentes ao âmbito de seu foro íntimo ${ }^{10}$.

Em artigo veiculado na Folha de São Paulo, de 29/10/2004, citado Ministro sugere uma análise empática da situação: "Para aguçar o termômetro da sensibilidade, é de bom alvitre perguntar a si mesmo, antes de qualquer decisão: e se fosse com a minha filha, minha mulher, minha irmã? Suportaria esses nove meses de tormento, de espera sem esperança?"11.

Ronald Dworkin (2003, p. 27), em sua obra “Domínio da Vida: Aborto, eutanásia e liberdades individuais", demonstra a dissonância que pode existir entre a retórica e a ação de determinados indivíduos.

Lembra o autor que na campanha presidencial de 1992, nos Estados Unidos, tanto Bush - presidente, quanto Quayle - vice-presidente, defenderam estridente e irredutivelmente as opiniões "pró-vida", em seus termos mais ortodoxos. Expressaram publicamente, porém, que apoiariam sua própria filha ou neta se decidissem pelo abortamento, conduta lícita no país.

Além de comprovar referida dissociação, o fato põe em evidência outra questão: o Executivo e o Legislativo são sensíveis à força política de determinados grupos, e é inegável a força dos grupos religiosos no Brasil e em outros países ${ }^{12}$.

Outro importante aspecto a ser ressaltado, é que a questão do aborto é matéria de Saúde Pública.

Segundo informações da Organização Mundial da Saúde, "Redução da Mortalidade Materna", de 1999, a causa mais freqüente da morte materna no mundo é a hemorragia (25\%), seguida da morte resultante de infecções (15\%), e, em terceiro lugar, do falecimento devido às complicações do aborto $(13 \%)^{13}$.

${ }^{10}$ Comentário disponível em: $<h t t p: / / w w w . s t f . g o v . b r>$

11 Disponível em: <http://www1.folha.uol.com.br/fsp/opiniao/fz2910200409.htm>

12 Em Portugal, o Partido Popular CDS-PP (Centro Democrático e Social), que tem uma posição oficial contra a despenalização do abortamento, e o PSD (Partido Social Democrata), parceiro de coligação, que não mantinha uma posição oficial sobre a matéria, firmaram o seguinte acordo, em 2002: os líderes Paulo Portas (CDS-PP) e Durão Barroso (PSD) comprometeram-se a não alterar a atual lei portuguesa durante toda a legislatura, isto é, de 2002 até 2006. Disponivel em: <http://www.portugaldiario.iol.pt>

13 Dados retirados do relatório da CPI da Mortalidade da Mulher (p. 39), disponível em $<h t t p: / / w w w . c a m a r a . g o v . b r>$. O relatório traz, ainda, dados referentes às causas de óbitos maternos em cada Estado do Brasil. 
Não se pode olvidar, ainda, que existe uma subnotificação geral sobre o aborto, devido à ilegalidade da prática em inúmeros países. Assim, os índices atribuídos às hemorragias e infecções podem estar a encobrir tentativas de aborto realizado em máscondições.

Encontra-se como perfil das vítimas, com alto risco de morte materna, mulheres de baixa renda ${ }^{14}$, pouca escolaridade e sem profissão definida.

Apresentado este panorama, resta saber se há, no Brasil, a criminalização da interrupção antecipada do processo gestacional quando o concepto é anencefálico, e, se houver, se é legítima no Estado Democrático de Direito brasileiro, ainda que respeitadas as regras da democracia política representativa.

\section{Aspectos jurídico-filosóficos: procedimentalismo versus substancialismo}

Mais do que interpretações distintas de uma mesma norma, o que aflora nas decisões judiciais já destacadas no presente trabalho são posições filosóficas divergentes entre os julgadores.

Com efeito, para aqueles que entendem que o ato de interromper a gravidez do concepto anencefálico constitui conduta típica, não albergada pelas excludentes de antijuridicidade pelo Legislador pátrio, resta a indagação sobre os limites da atividade jurisdicional: poderia o Judiciário exercer atividade criativa, sem que houvesse a politização (in)desejada deste órgão estatal, no exercício de competências legislativas? Respeito à separação de poderes e concretização dos direitos fundamentais... Afinal, qual o papel do julgador no Estado Constitucional Democrático de Direito?

Nos apropriando dos dizeres de $\operatorname{STRECK}(2004$, p.40), "sem pretender reduzir a discussão a uma polarização a duas posições ou teses, mas correndo (e assumindo) o risco de assim fazer, é possível assentar o problema a partir de dois eixos analíticos: 0 procedimentalismo e o substancialismo".

14 É sabido que gestantes que possuem recursos financeiros e desejam interromper a gestação acabam por praticar o ato em segurança em países onde a conduta é tida como lícita. Ronald Dworkin (2003, p. 4-5) relata que, após polêmica liminar judicial na Irlanda proibindo uma jovem de ir à Inglaterra interromper sua gestação, convocou-se um referendo, em novembro de 1992, no qual os cidadãos irlandeses recusaram-se a descriminalizar o abortamento, mas aprovaram uma emenda que declarava que as mulheres que estivessem decididas a abortar poderiam viajar ao exterior, e que informações sobre serviços desta natureza, prestados no exterior, teriam livre circulação na Irlanda. 
O papel do juiz no Estado Democrático de Direito: por uma perspectiva garantista no julgamento do caso da interrupção da gestação do concepto anencefálico submetido à jurisdição constitucional

Numa compreensão procedimentalista, o julgador, ao desempenhar a atividade jurisdicional, deve ser guiado pela função de protetor do processo de criação democrática representativa do direito; perquirir-se se para a elaboração da norma houve respeito ao procedimento estatuído na Lei Maior e à competência do órgão da qual emana.

O Estado Democrático é, ainda numa visão procedimentalista, mais efetivo quanto mais se garanta o acesso aos mecanismos da participação democrática, não havendo que se falar em uma ordem suprapositiva de valores substanciais apta a legitimar a atividade criativa do Judiciário, haja ou não inércia do Legislativo.

O gigantismo do Judiciário, criador de normas gerais e abstratas em usurpação da competência legislativa, parece, para os juristas procedimentalistas, ir de encontro à definição rosseauística de liberdade como "a obediência à lei que nós mesmos nos prescrevemos" (ROSSEAU, apud BOBBIO, 1992, p. 86), ou à definição de liberdade jurídica por Kant (KANT, apud BOBBIO, 1992, p. 86) como "a faculdade de só obedecer às leis externas às quais pude dar o meu assentimento".

Como fundamento do governo democrático, a regra da maioria. Como função central, a legislação política.

Habermas (1997), um dos adeptos à referida teoria, propõe a democracia como sendo um processo dialógico, travado no espaço público e transmitido ao sistema político, rumo à formação de consensos.

Reconhece o pluralismo social e afirma que os fluxos comunicativos produzidos na esfera pública são transmitidos ao sistema político, onde são sintetizados a fim de torná-los interesses generalizáveis para toda a sociedade ${ }^{15}$.

Dissipa-se, assim, na visão do eminente jurista alemão, as desigualdades social, política e econômica dos grupos e assegura-se a formação democrática da opinião e da vontade, não se recorrendo a valores substantivos.

Fosse o grupo majoritário tolerante o bastante para, no processo dialógico, respeitar interesses primários de todos, ainda que não the fossem vantajosos, o modelo procedimentalista talvez pudesse ser aplicado.

15 Derivação da vontade geral de Rosseau. 
Há, porém, nas Constituições atuais, dentre as quais a brasileira, de um lado os direitos fundamentais elencados, cláusulas pétreas em nosso ordenamento, e, de outro lado, sua inefetividade, resultando na inegável condição de marginalização da minoria.

Passa-se à compreensão substancialista. Nesta, a democracia vai além do respeito às "regras do jogo".

A existência de desigualdades social e econômica traduz-se na dificuldade de determinados grupos sociais em acessar os poderes políticos, sendo preteridos em sua vontade.

Sustentando a tese substancialista, Mauro Cappelletti (1993, p. 99 e ss.) argumenta que os Tribunais podem, através da interpretação criativa, dar importante contribuição à "representatividade geral do sistema". No processo judicial ocorre, na lição do jurista italiano, uma inclusão dos grupos minoritários no debate político social. Vocalizam-se as expectativas e direitos dos grupos marginais que, na arena legislativa, são inaptos a demonstrar grande força política.

Cappelletti destaca, em contra-argumento à afirmação de inexistência de uma adstrição procedimental para a elaboração da norma fora das vias legislativas, que no Judiciário encontram-se rígidos procedimentos a serem seguidos, procedimentos judiciais que envolvem desde a inércia do órgão ${ }^{16}$, que só pode vir a se pronunciar sobre um caso trazido pelas partes à julgamento, até os limites processuais e as amplas garantias ao contraditório e à defesa, dispensando-se tratamento igualitário aos indivíduos.

Afirmando entender a essencialidade do "sentimento de participação" no governo democrático, ressalta que nos casos de grupos minoritários há a quase inacessibilidade aos legisladores e seus aparelhos burocráticos. O "sentimento de participação", neste caso, seria melhor suprido pela faculdade de iniciar o processo jurisdicional e determinar o seu conteúdo. Neste diapasão, para Cappelletti (1993, p. 100), “o processo jurisdicional é até o mais participatório de todos os processos da atividade pública.".

Observa Mauro Cappelletti que os governos democráticos são os únicos onde os direitos e garantias fundamentais têm a potencialidade de serem respeitados, e que a recíproca é verdadeira, ou seja, a democracia é derrogada em um sistema onde estes direitos e garantias não encontrem real proteção.

16 Que CAPPELLETTI (1993, p. 73) destaca como "virtudes passivas da Justiça”. 
O papel do juiz no Estado Democrático de Direito: por uma perspectiva garantista no julgamento do caso da interrupção da gestação do concepto anencefálico submetido à jurisdição constitucional

Também advogando tese substancialista, Ferrajoli $(2002)^{17}$, chama-nos à atenção de que a constitucionalização rígida dos direitos fundamentais traz, inexoravelmente, a dimensão substancial da democracia: na Constituição encontram-se mais do que normas de organização dos poderes a gizar "quem" e "como" decidir no cenário político, mas normas substantivas, direitos e garantias fundamentais, a acenar para o que se pode e o que não se pode decidir nem mesmo por maioria, e o que se deve e não se deve decidir ainda que contra a vontade desta mesma maioria.

A relação entre o direito e política se inverte na visão de Ferrajoli: é a política o instrumental para a garantia dos direitos fundamentais e dos princípios axiológicos postos pela Constituição, subordinada, portanto, a vínculos negativos, como os direitos à liberdade que não pode ser violada, e positivos, os direitos sociais, que também exigem concretização.

Através de uma análise do Estado de Democrático e do Estado de Direito, o ilustre jurista sistematiza as bases conceituais e metodológicas do chamado "garantismo jurídico", destacando a existência de três acepções do termo, a que passamos a expor.

\subsection{Teoria geral do garantismo}

Numa primeira acepção, o garantismo é identificado como modelo normativo estruturado sobre o princípio da legalidade, base do Estado de Direito.

Ferrajoli apresenta o Estado de Direito como Estado limitado pelos direitos fundamentais, criador, portanto, de um sistema de proteção dos cidadãos imponível contra o próprio Estado e, até mesmo, contra os grupos majoritários.

Um Estado guiado por uma Constituição que estabelece, como já se mencionou, o que deve e o que não deve ser legislado, seja em prol dos direitos fundamentais individuais Estado de Direito Liberal, ou dos direitos fundamentais sociais - Estado de Direito Social, ou em prol de ambos.

Mais ainda: um ente estatal que, além de exercer a auto-limitação ante o reconhecimento dos direitos fundamentais, prevê mecanismos hábeis a garanti-los, concretizálos.

17 Um estudo sistematizado da teoria do garantismo, pautada nas obras de Ferrajoli, foi realizado por CARDEMATORI (1999). 
Numa segunda acepção, é tido como modelo de "deslegitimação interna ${ }^{18}$ das normas vigentes e inválidas".

Salienta que a validade de uma norma é auferida após submetê-la ao crivo de dois julgamentos, um envolvendo juízo de fato, e outro, juízo de valor.

Quando se analisa a norma perquirindo-se se foram respeitados os procedimentos estatuídos na Lei Maior para sua elaboração e a competência do órgão da qual emana, submete-a a um juízo de fato, e constata-se a "validade formal" daquela. Diz-se, assim, que a lei ou ato normativo é vigente.

Quando se questiona, porém, se seu conteúdo vai ao encontro dos valores constitucionais, das garantias dos direitos dos cidadãos, faz-se um juízo de valor, e constatase a "validade substancial". Afirma-se, então, que ato normativo, ou a lei, é válido(a).

O Estado Democrático pressupõe, segundo Ferrajoli, a conformação das leis aos juízos de fato, ou seja, a validade formal de suas normas. O Estado Democrático de Direito, de outro lado, a validade formal e a substancial.

Por fim, o garantismo assume uma terceira acepção, de ordem jurídicofilosófica, um modelo de "deslegitimação externa das instituições jurídicas positivadas".

Assume o eminente jurista uma posição abertamente heteropoiética na qual, mesmo admitindo a distinção entre moral e direito, ponto de vista jurídico ou interno e ponto de vista ético-político ou externo, retira do Estado positivador de normas sua relevância como centro de legitimação, transferindo-o à sociedade, com sua multiplicidade de pessoas, forças e classes sociais. A legitimação dá-se de fora para dentro, de baixo para cima: o Estado é visto como um ente artificial delimitado, como já dissemos, pelos direitos fundamentais, visando à proteção dos direitos dos cidadãos.

\subsubsection{Da síntese da Democracia Substancial e da Democracia Procedimental e o Estado Democrático de Direito}

Propondo uma releitura do conceito de democracia no âmbito do Estado de Direito, Ferrajoli harmoniza a democracia procedimental ou formal, respaldada no princípio da

18 Ferrajoli utiliza com freqüência os termos "interno" e "externo" correspondendo, respectivamente, a "jurídico" e "extrajurídico", leia-se político, ético, moral . 
O papel do juiz no Estado Democrático de Direito: por uma perspectiva garantista no julgamento do caso da interrupção da gestação do concepto anencefálico submetido à jurisdição constitucional

maioria, com a democracia substancial, que giza pelo respeito aos direitos fundamentais, inclusive àqueles atinentes às minorias marginalizadas.

Se traz o autor italiano como verdade que a premissa do Estado de Direito Liberal é que "nem sobre tudo se pode decidir" e a do Estado de Direito Social aquela que preceitua que "nem sobre tudo se pode não decidir", num e noutro caso até mesmo contra a vontade do grupo majoritário, também leciona que, sobre tudo o mais vale a regra da democracia política, vale dizer, a decisão se dá, direta ou indiretamente, pela vontade da maioria dos cidadãos.

Neste sentido, o Estado de Direito equivaleria à democracia, tutelando, além da vontade da maioria, os interesses e necessidades vitais de todos.

Os dois modelos de democracia, a do "Estado político representativo" e a do "Estado de Direito", ainda que de possível existência independente, estariam indissociados no Estado Democrático de Direito.

Enquanto a legitimidade do exercício da soberania, no Estado representativo, está na inafastável observância da vontade da maioria; é exigido das instituições políticas e jurídicas, no Estado de Direito, que atuem como instrumento de concretização dos interesses primários de todos, sendo tanto mais legítimo o exercício do poder, quanto mais focado na tutela e efetivação dos direitos fundamentais.

Para o modelo garantista de Ferrajoli, nem mesmo as lacunas jurídicas, violação do ordenamento por meio de ato omissivo do Poder Legislativo, que aflige principalmente o Estado de Direito Social com seus direitos fundamentais positivos a serem efetivados, justificam a passividade do julgador.

Ao contrário, considerando a análise da legitimidade do exercício poder apresentada pelo jurista, a abstenção do julgador ratificaria a atuação ilegítima do Poder Legislativo que, tendo o dever de decidir, ainda que contra a vontade do grupo majoritário, não o fez.

O mesmo pensamento é aplicado, pelo formulador da teoria geral do garantismo, para as antinomias jurídicas: violando o dever de se abster de emitir decisão sobre determinada matéria, em prol de valores jurídicos de todos os indivíduos, o legislador cria norma jurídica inválida, que há de ser inexoravelmente afastada pelas instituições jurídicas, pena de incorrer na mesma ação ilegítima a que incorreu o Poder Legislativo. 


\section{Por uma perspectiva garantista no julgamento do caso da interrupção da gestação do concepto anencefálico}

Bobbio, ainda que defendendo os direitos fundamentais não como fundantes em si mesmos, direitos naturais do homem, mas sim como direitos conquistados historicamente, sustenta o direito de liberdade como "um dos pontos mais firmes do pensamento político universal, do qual não mais se pode voltar atrás" (BOBBIO, 1992, p. 99-100).

Por outro lado, a vida é um bem jurídico inestimável; nas palavras de Dworkin (2003, p. 43), "um dos deveres mais centrais e indiscutíveis do governo".

Mas seria a vida, no ordenamento jurídico pátrio, um bem absoluto?

A Legislação penal brasileira, ao criminalizar o abortamento, adota uma posição moderada: prevê circunstâncias excepcionais em que exclui a antijuridicidade do ato, quais sejam, em caso de aborto necessário e de aborto sentimental.

Há que se destacar, embora seja evidente, que quando se estatuiu as duas hipóteses do artigo 128 do Código Penal, considerou o Legislador que o concepto estivesse vivo no momento anterior às manobras abortivas, porque senão, aborto não se configuraria.

No caso do aborto necessário, há a ponderação entre o mesmo bem jurídico (vida), com sujeitos diversos (gestante e feto). No aborto sentimental, há a ponderação de bens jurídicos distintos, a vida do feto, e a saúde psíquica e a dignidade da pessoa da gestante. Ainda que diante de bens jurídicos diversos, a proteção da vida do feto, no caso do aborto sentimental, foi relativizada, tornando-se possível, através do exercício da autonomia da vontade da gestante, a escolha pela proteção à saúde psíquica desta.

Como já se destacou, pela Legislação brasileira o final jurídico da vida é a morte encefálica.

Parece mais correta, portanto, a interpretação de que não existe abortamento na antecipação da gestação do feto portador de anencefalia.

Ressalte-se que, não havendo bens jurídicos a serem ponderados, resta a tutela aos direitos fundamentais da gestante ${ }^{19}$ e carece ao Estado legitimidade para estender sobre a ação sua força punitiva, ainda que pela vontade da maioria.

19 Não se pode olvidar que, em seu tipo objetivo, o aborto prevê a necessidade de que o feto esteja vivo quando da interrupção da gestação. Não seria plausível relativizar a proteção à vida do feto em prol da 
O papel do juiz no Estado Democrático de Direito: por uma perspectiva garantista no julgamento do caso da interrupção da gestação do concepto anencefálico submetido à jurisdição constitucional

Invocando a lição de Ferrajoli (2002, p. 694): “Nenhuma maioria, se tem dito, pode decidir a condenação de um inocente ou a privação de direitos fundamentais de um sujeito ou de um grupo minoritário (...).".

Ainda que chegue o Supremo Tribunal Federal à outra conclusão, espera-se que a entrega da jurisdição reflita a postura legítima do juiz num Estado Democrático de Direito; não um juiz "boca da lei", mas um juiz capaz de sopesar valores, afastar normas inválidas e proferir sua decisão suprindo, até mesmo, a omissão legislativa, tudo com o fim de concretizar os direitos fundamentais postos na Constituição Federal. Um juiz cônscio da abrangência da democracia no Estado Constitucional Democrático de Direito, síntese da democracia substancial e da democracia formal-representativa.

\section{Considerações finais}

Face à disparidade entre a teoria e a práxis em matéria de direitos fundamentais, e a existência de grupos marginalizados na arena política, a visão substancialista, apresentada no presente artigo, tende a se firmar como posição filosófica necessária para concretização de valores substanciais postos pelas atuais Constituições e, até mesmo, para o fortalecimento da representatividade geral do sistema democrático.

Da análise da teoria do garantismo, de caráter eminentemente substancialista, clareiam-se as questões sobre a legitimação das decisões judiciais: serão legítimas quando garantirem efetividade às normas jurídicas válidas e, ainda, negarem tal atributo às inválidas. Serão legítimas quando concretizarem direitos fundamentais, não se olvidando que estes devem ser concretizados ainda que contra a vontade da maioria, isso se estabelecidos na Constituição de um Estado Democrático de Direito.

A adoção do modelo de Estado Democrático de Direito implica na postura ativa do juiz. Não basta que se lamente a omissão do Legislador e, assim, se negue efetividade aos direitos fundamentais postos no ordenamento.

O modelo de Estado em comento pressupõe a democracia em seu mais completo sentido, a convivência entre a democracia substancial e a democracia formalrepresentativa; a defesa "dos grupos minoritários" ainda que ao dissabor "da maioria". pratica uma interrupção do processo gestacional de um ser já considerado juridicamente morto. 
Uma perspectiva procedimentalista-garantista para a solução do caso da interrupção do concepto anencefálico é guiada por uma análise laica da questão, não se olvidando, porém, dos reflexos da decisão no âmbito social. A interpretação teleológica e sistemática do Código Penal e da Legislação pertinente ao marco inicial e final da vida, tudo conforme a Constituição, leva à conclusão de que, no Brasil, o fato é atípico. E mais, haja vista as posições Legislativas já expostas e sendo o Brasil um Estado Democrático de Direito, resta a tutela aos direitos fundamentais da gestante, carecendo ao Estado legitimidade para estender sobre a ação sua força punitiva.

A jurisdição constitucional, em que pese lenta, deve servir, nas palavras do ilustre Ministro do Supremo Tribunal Federal, Sr. Joaquim Barbosa ${ }^{20}$, quando do voto da questão de ordem Argüição de Descumprimento de Preceito Fundamental 54-8, ao "alargamento da ação protetiva dos direitos fundamentais".

Se assim for, um possível engessamento dos demais órgãos do Poder Judiciário será compensado pela concretização dos direitos fundamentais!

\section{Referências}

BARBOSA, Joaquim. Argüição de Descumprimento de Preceito Fundamental 54-8, [Voto de Questão de Ordem] Disponível em: <http://www.stf.gov.br>. Acesso em: 09 set. 2005

BARROSO, Luís Roberto. Argüição de Descumprimento de Preceito Fundamental 54-8 [Petição inicial]. Disponível em: <http://www.stf.gov.br>. Acesso em: 09 set. 2005.

BRASIL. Decreto-lei no 2.848, de 07 de dezembro de 1940. Código Penal Brasileiro.

BOBBIO, Norberto. A Era dos Direitos. Rio de Janeiro: Campus, 1992.

CADERMATORI, Sergio U. Estado de Direito e Legitimidade: Uma Abordagem Garantista. Porto Alegre: Livraria do Advogado, 1999.

CAPPELLETTI, Mauro. Juízes Legisladores. Trad. Carlos Alberto Álvaro de Oliveira. Porto Alegre: Sergio Antônio Fabri, 1993.

DWORKIN, Ronald. O domínio da Vida: Aborto, Eutanásia e Liberdades Individuais. Trad. Jefferson Luiz Camargo. São Paulo: Martins Fontes, 2003.

20 Disponível em: <http://www.stf.gov.b>. Acesso em 09.09.2005. 
O papel do juiz no Estado Democrático de Direito: por uma perspectiva garantista no julgamento do caso da interrupção da gestação do concepto anencefálico submetido à jurisdição constitucional

. Uma questão de princípio. Trad. Luiz Carlos Borges. São Paulo: Martins Fontes, 2005.

FERRAJOLI, Luigi. Direito e Razão: Teoria do Garantismo Penal. São Paulo: Revista dos Tribunais, 2002.

HABERMAS, Jürgen. Direito e Democracia: Entre Facticidade e Validade. Trad. Flávio Beno Sieneichler. Rio de Janeiro: Tempo Brasileiro, 1997.

MELLO, Marco Aurélio Mendes de Faria. A dor a mais. Folha de São Paulo. Sexta, 29/10/2004. Disponível em:

<http://www1.folha.uol.com.br/fsp/opiniao/fz2910200409.htm>. Acesso em: 13 nov. 2005.

PIOVESAN, Flávia;PIMENTEL, Sílvia. Fórum Debates: Revisão da Legislação sobre o Aborto. Revista Consulex. Prática Jurídica, v. 4, n. 36, 31 mar. 2005.

SARLET, Ingo Wolfgang. Argüição de Descumprimento de Preceito Fundamental: alguns aspectos controversos. Revista Diálogo Jurídico, Salvador, CAJ - Centro de Atualização Jurídica, v. 1, n. 3, jun. 2001. Disponível em: <http://www.direitopublico.com.br>. Acesso em: 19 set. 2005.

STRECK, Lênio Luiz. Jurisdição Constitucional e Hermenêutica: uma nova crítica do direito. Porto Alegre: Livraria do Advogado, 2002. 
